\title{
Faktor yang Mempengaruhi Tingkat Kepercayaan Penggunaan FinTech pada UMKM Dengan Menggunakan Technology Acceptance Model (TAM)
}

\author{
Suyanto, Taufan Adi Kurniawan \\ Program Studi Akuntansi Fakultas Ekonomi \\ Universitas Sarjanawiyata Tamansiswa Yogyakarta \\ Email: iyant@ustjogja.com
}

\begin{abstract}
In recent years there have been alternative technology-based capital sources called FinTech, some MSMEs have begun using FinTech as an alternative source of capital, but several other MSMEs have chosen not to use FinTech because of risks such as data confidentiality, hacker attacks and fraud. This study aims to analyze the influential factors for MSMEs in utilizing technology-based FinTech as an alternative source of capital by using the technology acceptance model (TAM) by Davis by using random purposive sampling. This study shows that Ability to Use Computers (CSE), does not affect the Perception of Use (POU) on FinTech Software. The ability to use computers (CSE) has a positive effect on the Perception of Ease of Use (PEU) on FinTech Software. Perception of Ease of Use (PEU) Has a Positive Effect on the Perception of Use (POU) of FinTech Software. Perception of Use (POU) Has Positive Impact on User Attitudes (ATU) of FinTech Software. Perception of Ease of Use (PEU) does not affect the User Attitude (ATU) of FinTech Software. User Attitude (ATU) FinTech Software Has a Positive Effect on Behavior Interest (BEI). Interest in behavior (BEI) does not affect the actual use (ACU) of FinTech Software.
\end{abstract}

Keywords: Financial Technology, Technology Acceptance Model, MSME.

\begin{abstract}
ABSTRAK
Pada beberapa tahun belakangan ini terdapat sumber permodalan alternatif berbasis teknologi yang disebut FinTech, beberapa UMKM mulai menggunakan FinTech sebagai sumber permodalan alternatif, namun beberapa UMKM lain memilih tidak memanfaatkan FinTech karena risiko yang ada seperti kerahasiaan data, serangan peretas hingga penipuan. Penelitian ini bertujuan untuk menganalisis faktor-faktor yang berpengaruh bagi UMKM dalam memanfaatkan FinTech yang berbasis teknologi sebagai sumber modal alternatif dengan menggunakan model penerimaan teknologi atau Technology Acceptance Model (TAM) oleh Davis dengan random purposive sampling. Pengujian hipotesis pada penelitian ini menunjukkan bahwa Kemampuan Menggunakan Komputer (CSE), tidak berpengaruh terhadap Persepsi Kegunaan (POU) pada Perangkat Lunak FinTech. Kemampuan menggunakan komputer (CSE) berpengaruh Positif terhadap Persepsi Kemudahan Penggunaan (PEU) pada Perangkat Lunak FinTech. Persepsi Kemudahan Penggunaan (PEU) Berpengaruh Positif terhadap Persepsi Kegunaan (POU) Perangkat Lunak FinTech. Persepsi Kegunaan (POU) Berpengaruh Positif terhadap Sikap Pengguna (ATU) Perangkat Lunak FinTech. Persepsi Kemudahan Penggunaan (PEU) tidak Berpengaruh terhadap Sikap Pengguna (ATU) Perangkat Lunak FinTech. Sikap Pengguna (ATU) Perangkat Lunak FinTech Berpengaruh Positif terhadap Minat Perilaku (BEI). Minat perilaku (BEI) tidak Berpengaruh Positif terhadap Penggunaan Senyatanya (ACU) Perangkat Lunak FinTech.
\end{abstract}

Kata Kunci: Financial Technology, Technology Acceptance Model, UMKM. 


\section{PENDAHULUAN}

Teknologi informasi dalam dunia keuangan bukanlah suatu hal yang baru, terkadang terdapat suatu layanan yang terkendala dengan biaya, kebiasaan pengguna, serta kandungan risiko sehingga beberapa layanan keuangan berbasis teknologi informasi menunggu kesiapan dari berbagai segi sehingga siap untuk dimanfaatkan secara optimal.

FinTech merupakan teknologi yang memanfaatkan jejaring internet berawal dari tahun 1966 dengan tujuan untuk mengembankan bisnis secara global. Pada sekitar tahun 1980 bank mulai menggunakan Fintech untuk mempermudah pekerjaan perbankan, kemudian pada tahun 1990 dengan adanya dukungan dari teknologi jejaring internet yang semakin stabil maka penggunaan Fintech semakin berkembang, seperti misalnya online banking dengan dukungan perangkat lunak dan jejaring internet yang memadai maka masyarakat telah mulai terbiasa dengan penggunaan Fintech.

Tahun 1998 adalah saat di mana bank mulai mengenalkan online banking untuk para nasabahnya. FinTech pun menjadi semakin mudah digunakan masyarakat luas, juga makin dikenal. Pembayaran yang praktis dan jauh berbeda dengan metode pembayaran konvensional membuat perkembangan FinTech semakin gencar. Layanan finansial yang lebih efisien dengan menggunakan teknologi dan piranti lunak dapat dengan mudah diraih dengan FinTech.

Bank Indonesia sebagai regulator telah membuat klasifikasi melalui Junanto Herdiawan selaku Acting Head of Financial Technology Bank Indonesia tentang Fintech di Indonesia menjadi 4 jenis yaitu:

1. Crowdfunding dan Peer- to-Peer $(P 2 P)$ Lending

2. Market Aggregator

3. Risk and Investment Management

4. Payment, Settlement, and Clearing

Seiring dengan berkembangnya FinTech di Indonesia para pelaku UMKM sering menggunakan jasa layanan keuangan terutama dalam bentuk peer-to-peer lending untuk menambah modal usaha karena lebih memiliki keuntungan dibanding dengan bank konvensional, namun dibalik kemudahan yang ada pada FinTech terdapat juga beberapa risiko yang dapat sangat membahayakan bagi para pengguna. Beberapa risiko yang dapat diidentifikasi adalah:

1. Perlindungan konsumen

a. Perlindungan dana pengguna

Potensi kehilangan maupun penurunan kemampuan finansial baik yang diakibatkan oleh penyalahgunaan, penipuan, maupun force majeur dari kegiatan kegiatan FinTech.

b. Perlindungan data pengguna

Isu privasi pengguna pengguna FinTech yang rawan terhadap penyalahgunaan data baik yang yang disengaja maupun tidak disengaja (serangan hacker, malware, dll )

2. Kepentingan Nasional

a. Anti Pencucian Uang dan Pencegahan Pendanaan Terorisme (APU-PPT)

Kemudahan dan kecepatan yang ditawarkan oleh FinTech menimbulkan potensi penyalahgunaan untuk kegiatan pencucian uang maupun pendanaan terorisme.

b. Stabilitas Sistem Keuangan

Perlu manajemen risiko yang memadai agar tidak berdampak berdampak negatif terhadap stabilitas sistem keuangan.

Dengan adanya kemudahan dan risiko pada penggunaan FinTech, namun tetap tidak menyurutkan minat dari UMKM untuk menggunakan FinTech sebagai alternatif sumber permodalan. Data dari OJK menyebutkan bahwa FinTech tumbuh dari 2013-2014 terdapat 40 perusahaan Fintech kemudian naik pada tahun 2015-2016 menjadi 165 perusahaan FinTech dengan bidang lending mengambil pangsa pasar FinTech sebesar $17,78 \%$. Hal ini tentu menjadi fenomena yang menarik dipelajari, dengan kemudahankemudahan yang di dapat serta risiko yang ada ternyata tidak menyurutkan minat pegiat UMKM untuk tetap menggunakan FinTech sebagai sumber permodalan alternatif selain bank konvensional. aPertanyaan yang muncul kemudian adalah "apa yang menjadi alasan UMKM untuk memilih FinTech sebagai 
alternatif permodalan? apakah karena kebermanfaatannya ataukah lebih pada kemudahan dalam akses dan penggunaannya?".

\section{KAJIAN LITERATUR}

\section{Definisi UMKM}

Pada UU No. 20 Tahun 2008 tentang Usaha Kecil, Mikro dan Menengah atau yang biasa disingkat UMKM mempunyai definisi sebagai berikut:

1. Usaha Mikro adalah usaha produktif milik orang perorangan dan/atau badan usaha perorangan yang memenuhi kriteria Usaha Mikro sebagaimana diatur dalam UndangUndang yaitu memiliki kekayaan bersih paling banyak Rp50.000.000,00 (lima puluh juta rupiah) tidak termasuk tanah dan bangunan tempat usaha; atau memiliki hasil penjualan tahunan paling banyak Rp300.000.000,00 (tiga ratus juta rupiah).

2. Usaha Kecil adalah usaha ekonomi produktif yang berdiri sendiri, yang dilakukan oleh orang perorangan atau badan usaha yang bukan merupakan anak perusahaan atau bukan cabang perusahaan yang dimiliki, dikuasai, atau menjadi bagian baik langsung maupun tidak langsung dari Usaha Menengah atau Usaha Besar yang memenuhi kriteria Usaha Kecil sebagaimana dimaksud dalam Undang-Undang yaitu memiliki kekayaan bersih lebih dari Rp50.000.000,00 (lima puluh juta rupiah) sampai dengan paling banyak Rp500.000.000,00 (lima ratus juta rupiah) tidak termasuk tanah dan bangunan tempat usaha; atau memiliki hasil penjualan tahunan lebih dari Rp300.000.000,00 (tiga ratus juta rupiah) sampai dengan paling banyak Rp2.500.000.000,00 (dua milyar lima ratus juta rupiah).

3. Usaha Menengah adalah usaha ekonomi produktif yang berdiri sendiri, yang dilakukan oleh orang perorangan atau badan usaha yang bukan merupakan anak perusahaan atau cabang perusahaan yang dimiliki, dikuasai, atau menjadi bagian baik langsung maupun tidak langsung dengan Usaha Kecil atau Usaha Besar dengan jumlah kekayaan bersih atau hasil penjualan tahunan sebagaimana diatur dalam UndangUndang yaitu memiliki kekayaan bersih lebih dari Rp500.000.000,00 (lima ratus juta rupiah) sampai dengan paling banyak Rp10.000.000.000,00 (sepuluh milyar rupiah) tidak termasuk tanah dan bangunan tempat usaha; atau memiliki hasil penjualan tahunan lebih dari Rp2.500.000.000,00 (dua milyar lima ratus juta rupiah) sampai dengan paling banyak Rp50.000.000.000,00 (lima puluh milyar rupiah).

UMKM mempunyai peranan penting dan strategis dalam pembangunan ekonomi nasional. Selain berperan dalam pertumbuhan ekonomi dan penyerapan tenaga kerja, UMKM juga berperan dalam mendistribusikan hasilhasil pembangunan. UMKM juga telah terbukti tidak terpengaruh terhadap krisis. Data Badan Pusat Statistik memperlihatkan, pasca krisis ekonomi tahun 1997-1998 jumlah UMKM tidak berkurang, justru meningkat terus, bahkan mampu menyerap 85 juta hingga 107 juta tenaga kerja sampai tahun 2012. Pada tahun itu, jumlah pengusaha di Indonesia sebanyak 56.539.560 unit. Dari jumlah tersebut, UMKM sebanyak 56.534.592 unit atau 99.99\%. Sisanya, sekitar $0,01 \%$ atau 4.968 unit adalah usaha besar. Data tersebut membuktikan, UMKM merupakan pasar yang sangat potensial bagi industri jasa keuangan, terutama bank untuk menyalurkan pembiayaan. Karena sekitar 60$70 \%$ pelaku UMKM belum memiliki akses pembiayaan perbankan.

\section{Definisi FinTech}

Fintech adalah industri yang menggunakan teknologi TI yang berpusat pada ponsel untuk meningkatkan efisiensi sistem keuangan. "Fintech" sebagai istilah adalah gabungan "keuangan" dan "teknologi", dan secara kolektif mengacu pada perubahan industri yang berasal dari konvergensi layanan keuangan dan TI. Dalam hal layanan keuangan, ini adalah layanan inovatif yang menyediakan layanan keuangan terdiferensiasi menggunakan teknologi baru, seperti mobile, media sosial, dan 
IOT. Contoh terbaru adalah sistem pembayaran dan penyelesaian berbasis mobile, yang merupakan layanan yang paling representatif di Korea. Dari segi industri, mengacu pada fenomena dimana bisnis non-keuangan menggunakan teknologi inovatif untuk memberikan layanan, seperti pengiriman uang, pembayaran dan penyelesaian, dan investasi, tanpa bekerja sama dengan perusahaan keuangan. Contoh utamanya adalah Apple Pay dan AliPay.

\section{Definisi Technology Acceptance Model (TAM)}

TAM adalah salah satu ekstensi yang paling berpengaruh dari teori aksi penalaran atau Theory of Reasoned Act (TRA) oleh Ajzen dan Fishbein. Model TAM oleh Davis, Bagozzi \& Warshaw pada tahun 1989 adalah model penerimaan pengguna dan penggunaan teknologi yang paling banyak digunakan. Ini dikembangkan oleh Fred Davis dan Richard Bagozzi (Davis 1989, Bagozzi, Davis \& Warshaw 1992).

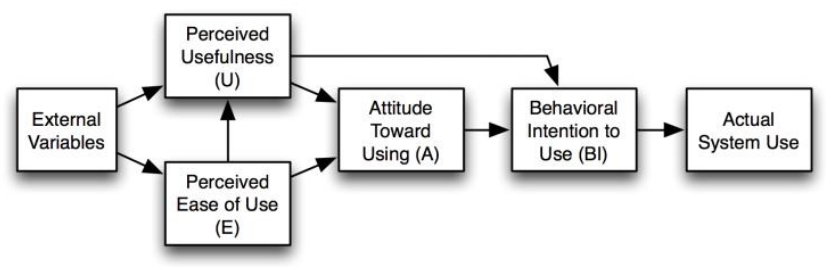

Gambar 1 Model TAM oleh Davis, Bagozzi \& Warshaw (1989)

TAM menggantikan banyak penelitian tentang TRA dengan dua pendekatan penerimaan teknologi dengan kemudahan penggunaan (ease of use), dan kegunaan (usefulness). TRA dan TAM, keduanya memiliki unsur perilaku yang kuat, menganggap bahwa ketika seseorang membentuk suatu niat untuk bertindak, maka mereka akan bebas untuk bertindak tanpa batasan. Di dunia nyata akan ada banyak kendala, seperti terbatasnya kebebasan untuk bertindak.

TAM digunakan untuk memprediksi penggunaan dan penerimaan pengguna berdasar pada persepsi kegunaan (perceived usefulness) dan persepsi kemudahan penggunaan (perceived ease of use). TAM memahami bahwa niat perilaku (behavioral intention) merupakan penentu yang signifikan dalam penggunaan sistem secara aktual, TAM juga menunjukkan bahwa niat perilaku ditentukan oleh dua hal penting yaitu persepsi kegunaan (perceived usefulness) dan persepsi kemudahan penggunaan (perceived ease of use). Persepsi kegunaan mengacu pada "tingkat kepercayaan sesorang bahwa penggunaan sistem tertentu akan meningkatkan kinerjanya". Persepsi kemudahan penggunaan mengacu pada "tingkat kepercayaan seseorang bahwa penggunaan sistem tertentu akan mengurangi atau membebaskan dari usaha fisik dan mental". Di TAM, keyakinan individu merupakan faktor penentu sikap individu untuk menggunakan sistem dan pada perkembangannya akan berlanjut pada sikap pengembangan niat untuk menggunakan sistem tersebut (intention to use), niat ini mempengaruhi keputusan penggunaan teknologi.

Dengan pesatnya teknologi Internet dan konvergensi, para periset telah memodifikasi TAM untuk menunjukkan bukti empirisnya dalam konteks konvergensi. Padahal, banyak peneliti telah mengajukan berbagai model TAM yang telah diperluas.

Misalnya, Moon dan Kim (2008) dalam Kim (2015) menyarankan sebuah model di mana persepsi permainan (perceived playfulness) yang dirasakan digambarkan sebagai salah satu anteseden sikap terhadap penelusuran web di internet. Mereka mencatat bahwa kebanyakan penelitian TAM sebelumnya hanya berfokus pada motivasi ekstrinsik, bukan pada motivasi intrinsik. Penelitian Morris dan Dillon (1997) dalam Kim (2015) menemukan bahwa TAM berkontribusi pada prediksi penggunaan perangkat lunak individual. Model motivasi yang diadaptasi oleh Davis, Bagozzi, Warshaw (1992) dalam Kim (2015) menggunakan dua konstruksi utama: motivasi ekstrinsik dan intrinsik. Menurut Venkatesh dan Speier (1999) dalam Kim (2015), motivasi ekstrinsik mengacu pada kinerja suatu aktivitas. Motivasi ekstrinsik dirasakan dapat membantu mencapai hasil yang dinilai tinggi yang berbeda 
dari aktivitas itu sendiri, seperti meningkatkan kinerja, gaji, dan sebagainya. Motivasi intrinsik mengacu pada kinerja suatu aktivitas tanpa alasan selain proses pengerjaannya.

Beberapa penelitian dengan menggunakan TAM juga dilakukan pada kasuskasus di Indonesia misalnya Hermanto dan Patmawati (2017) yang menguji pengaruh kemampuan menggunakan komputer, persepsi, sikap dan minat dalam menggunakan perangkat lunak akuntansi dengan pendekatan Technology Acceptance Model. Dengan sampel 104 mahasiswa akuntansi Sekolah Tinggi Ilmu Ekonomi Surabaya (STIESIA) tahun ajaran 2014/2015 yang telah menggunakan perangkat lunak akuntansi, dengan pengukuran konstruk kemampuan menggunakan komputer (computer self efficacy), persepsi kemudahan penggunaan (perceived ease of use), persepsi kegunaan (perceived usefulness), sikap (attitude toward using), minat (behavioral intention), dan penggunaan senyatanya (actual use) perangkat lunak akuntansi, melalui kuisioner. Hasil analisis menggunakan structural equation modeling-partial least squares menunjukkan bahwa kemampuan menggunakan komputer berpengaruh positif terhadap persepsi kemudahan (perceived ease of use). Persepsi kemudahan (perceived ease of use) dan persepsi kegunaan (perceived usefulness) berpengaruh positif terhadap sikap pengguna (attitude toward using). Sikap pengguna (attitude toward using) berpengaruh positif terhadap minat perilaku (behavioral intention). Minat perilaku (behavioral intention) berpengaruh positif terhadap penggunaan senyatanya. Sedangkan kemampuan menggunakan komputer (computer self efficacy) tidak mempengaruhi persepsi kegunaan (perceived usefulness) perangkat lunak akuntansi.

Napitupulu (2017) melakukan penelitian yang bertujuan untuk mengetahui gambaran keberhasilan penerapan e-learning berdasarkan penerimaan pengguna di lingkungan Universitas. Penerimaan pengguna dapat memprediksi tingkat pemanfaatan terhadap teknologi di masa yang akan datang. Melibatkan 73 orang sebagai responden yang dipilih dengan teknik purposive sampling. Hasil penelitian menunjukkan pengguna setuju dengan kebermanfaatan (perceived usefulness) sistem $e$ learning dengan persentase sebesar $69.12 \%$, pengguna juga setuju dengan kemudahan penggunaan (perceived ease of use) e-learning dengan persentase $69.80 \%$ dan pengguna secara keseluruhan setuju dengan penerimaan sistem elearning dengan persentase sebesar $72.69 \%$.

\section{Pengembangan Hipotesis}

Berdasar pada kajian-kajian literatur sebelumnya maka penulis tertarik untuk meneliti faktor-faktor yang mempengaruhi UMKM dalam memanfaatkan FinTech dengan menggunakan model TAM oleh Model TAM oleh Davis, Bagozzi \& Warshaw (1989). Dengan mengambil hipotesis sebagai berikut:

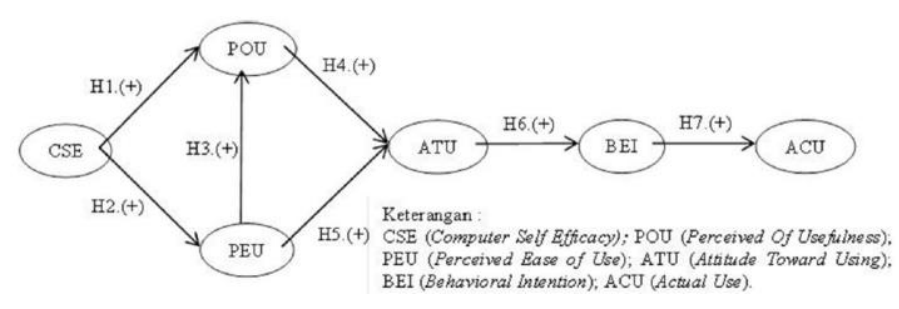

Gambar 2 Model Penelitian

\section{Hubungan Kemampuan Menggunakan Komputer (CSE) dengan Persepsi Kegunaan (POU) dan Persepsi Kemudahan Penggunaan (PEU).}

\section{Computer Self Efficacy (CSE)} menggambarkan persepsi individu tentang kemampuannya menggunakan komputer untuk menyelesaikan tugas-tugas seperti menggunakan Perangkat lunak untuk analisis data dan tugas lainnya. Kemampuan dalam mengoperasikan program komputer dapat mendorong individu memberikan pendapat mengenai kemudahan penggunaan sistem informasi yang ada. Bekerja dengan suatu sistem yang mampu menghasilkan kinerja yang baik serta cara mengoperasikannya tidak menimbulkan kesulitan akan membuat karyawan berpendapat bahwa sistem tersebut mudah digunakan.
Penelitian Hermanto \& Patmawati (2017) tidak menemukan kemampuan menggunakan komputer (CSE) berhubungan 
dengan persepsi kegunaan (POU) dan persepsi kemudahan (PEU). Sementara penelitian Farokhah \& Afiyah (2015) menemukan adanya hubungan antara CSE dengan PEU. Berdasar hal tersebut maka hipotesis yang terbentuk adalah:

H1: Kemampuan menggunakan komputer (CSE) berpengaruh positif terhadap persepsi kegunaan (POU) pada perangkat lunak FinTech.

H2: Kemampuan menggunakan komputer (CSE) berpengaruh positif terhadap persepsi kemudahan penggunaan (PEU) pada perangkat lunak FinTech.

\section{Hubungan Persepsi Kemudahan Penggunaan (PEU) dengan Persepsi Kegunaan (POU) dan Sikap Pengguna (ATU).}

Persepsi kemudahan penggunaan sebagai tingkat keyakinan seseorang bahwa dalam meng-gunakan sistem tertentu tidak diperlukan usaha yang keras, pada umumnya untuk menghindari penolakan dari pengguna sistem maka sistem harus mudah diaplikasikan oleh pengguna tanpa mengeluarkan usaha yang dianggap memberatkan.

Pada penelitian Hermanto \& Patmawati (2017) persepsi kemudahan penggunaan (PEU) memberikan pengaruh positif terhadap persepsi kegunaan (POU), dan persepsi kemudahan penggunaan (PEU) berpengaruh positif terhadap sikap pengguna (ATU). Berbeda dengan hasil penelitian Farokhah \& Afiyah (2015) yang mempunyai hasil penelitian persepsi kemudahan penggunaan (PEU) berpengaruh positif terhadap persepsi kegunaan (POU), sementara untuk persepsi kemudahan penggunaan (PEU) tidak berpengaruh terhadap sikap pengguna (ATU).

H3: Persepsi kemudahan penggunaan (PEU) berpengaruh positif terhadap persepsi kegunaan (POU) perangkat lunak FinTech.

H5: Persepsi kemudahan penggunaan (PEU) berpengaruh positif terhadap sikap pengguna (ATU) perangkat lunak FinTech.

Hubungan Persepsi Kegunaan (POU) dengan Sikap Pengguna (ATU)
Persepsi kegunaan (perceived usefulness) adalah sejauh mana seseorang percaya bahwa menggunakan suatu teknologi akan meningkatkan kinerjanya. Jika seseorang merasa percaya bahwa teknologi berguna maka dia akan menggunakannya. Sebaliknya jika seseorang merasa percaya bahwa tekologi kurang berguna maka dia tidak akan menggunakannya.

Penelitian sebelumnya menunjukkan bahwa konstruk kegunaan persepsian mempengaruhi secara positif dan signifikan terhadap penggunaan sistem informasi. Penelitian Farokhah \& Afiyah (2016) menunjukan bahwa persepsi kegunaan (POU) berpengaruh terhadap sikap pengguna (ATU). Hasil dari penelitian Hermanto \& Patmawati (2017) juga menunjukkan bahwa persepsi kegunaan (POU) mempunyai pengaruh positif terhadap sikap pengguna (ATU).

H4: Persepsi kegunaan (POU) berpengaruh positif terhadap sikap pengguna (ATU) perangkat lunak FinTech.

\section{Hubungan Sikap Pengguna (ATU) dengan Minat Perilaku (BEI)}

Attitude merupakan cermin perasaan suka atau tidak suka tentang kinerja dari target perilaku yang telah dilakukan (Davis 1989), dan behavioral intention to use sebagai kecenderungan atas perilaku pengguna untuk tetap menggunakan suatu teknologi (Davis 1989). Sikap yang berupa perasaan suka atau tidak suka dapat dijadikan faktor yang mempengaruhi minat atau keinginan seseorang dalam melakukan sesuatu. Penelitian Farokhah \& Afiya (2016) menunjukkan bahwa sikap pengguna (ATU) memberikan pengaruh terhadap minat perilaku (BEI), Hermanto \& Patmawati (2017) juga memberikan hasil yang serupa yaitu sikap pengguna (ATU) memberikan pengaruh terhadap minat perilaku (BEI).

H6: Sikap pengguna (ATU) perangkat lunak FinTech berpengaruh positif terhadap minat perilaku (BEI). 
Hubungan Minat Perilaku (BEI) dengan Penggunaan Senyatanya (ACU)

Minat Perilaku dapat digunakan sebagai alat prediksi yang baik terhadap penggunaan senyatanya (actual use). Minat (intention) mempunyai definisi sebagai suatu keinginan seseorang untuk melakukan suatu perilaku tertentu (Venkatesh et al. 2003). Pada penelitian Farokhah \& Afiya (2016) menunjukkan bahwa terdapat pengaruh yang positif dari minat perilaku (BEI) terhadap penggunaan senyatanya (ACU). Hal ini berbanding lurus dengan penelitian Hermanto \& Patmawati (2017) yang menunjukkan bahwa minat perilaku (BEI) berpengaruh positif terhadap penggunaan senyatanya (ACU).

H7: Minat perilaku (BEI) berpengaruh positif terhadap penggunaan senyatanya (ACU) perangkat lunak FinTech.

\section{METODA PENELITIAN}

\section{Populasi dan Sampel}

Populasi penelitian ini adalah para pegiat UMKM di daerah Yogyakarta. Untuk sampel penelitian ini mengambil para pegiat UMKM yang telah mengetahui tentang FinTech, baik yang telah memanfaatkan perangkat lunak FinTech sebagai sumber modal alternatif maupun para pegiat UMKM yang telah mengetahui FinTech namun belum memanfaatkan FinTech sebagai sumber modal alternatif. Pengambilan sampel menggunakan purposive random sampling untuk memilih sampel dan dipilah berdasar omset dari masingmasing UMKM.

\section{Definisi Operasional dan Variabel Penelitian}

Konstruk-konstruk yang digunakan dalam penelitian ini adalah kemampuan menggunakan komputer (computer self efficacy), persepsi kemudahan (perceived ease of use), persepsi kegunaan (perceived usefulness), sikap terhadap penggunaan (attitude toward using), minat perilaku (behavioral intention), dan penggunaan senyatanya (actual use). Pengukuran tiap-tiap konstruk menggunakan skala likert 1 sampai dengan 5 yang mempunyai arti sebagai berikut (1) sangat tidak setuju, (2) tidak setuju, (3) netral, (4) setuju, dan (5) sangat setuju. Konstruk dan pengukuran tersebut akan dirangkum dalam bentuk kuisioner yang selanjutnya akan diisi oleh sampel penelitian yang mewakili populasi.

\section{Teknik Analisis}

Teknik analisis untuk menguji hipotesis digunakan Struktural Equation Model-Partial Least Square (SEM-PLS), dengan melakukan evaluasi outer model dan inner model. Outer model merupakan model pengukuran untuk menilai validitas dan reliabilitas model, sedangkan inner model merupakan evaluasi struktural untuk menilai hubungan antara konstruk atau variabel laten. Hasil dari kuisioner tersebut kemudian akan di analisis dan menghasilkan suatu data pendukung hipotesis diterima atau tidak diterima.

\section{HASIL PENELITIAN}

\section{Uji Asumsi Klasik}

Tabel 1 menunjukkan gambaran responden dalam penelitian ini, yang meliputi jenis kelamin, usia, pendidikan terakhir, omset usaha per tahun dan lama usaha.

Tabel 1 Profil Responden

\begin{tabular}{lll}
\hline Profil Responden & Jumlah & Persentase \\
\hline Jenis Kelamin & & \\
Pria & 26 & $70,3 \%$ \\
Wanita & 11 & $29,7 \%$ \\
Usia & & \\
\hline$<21$ tahun & 2 & $5,4 \%$ \\
21-25 tahun & 3 & $8,1 \%$ \\
26-30 tahun & 4 & $10,8 \%$ \\
\hline$>30$ tahun & 28 & $75,7 \%$ \\
Pendidikan Terakhir & & \\
\hline SMA & 13 & $35,1 \%$ \\
D3 & 2 & $5,4 \%$ \\
S1 & 14 & $37,8 \%$ \\
S2 & 8 & $21,6 \%$ \\
Omset per Tahun & & \\
\hline$<$ Rp 300 juta & 26 & $70,3 \%$ \\
Rp 300 juta - Rp 2,5 & 9 & $24,3 \%$ \\
\hline
\end{tabular}




\begin{tabular}{lll}
\hline Profil Responden & Jumlah & Persentase \\
\hline $\begin{array}{l}\text { milyar } \\
\begin{array}{l}\text { Rp 2,5 milyar - Rp 50 } \\
\text { milyar }\end{array}\end{array}$ & 1 & $2,7 \%$ \\
>Rp 50 milyar & 1 & $2,7 \%$ \\
Lama Usaha & & \\
\hline$<2$ tahun & 9 & $24,3 \%$ \\
2-4 tahun & 15 & $40,5 \%$ \\
5-7 tahun & 3 & $8,1 \%$ \\
\hline 7 tahun & 10 & $27,0 \%$ \\
\hline
\end{tabular}

Sumber data: Data diolah

Berdasarkan Tabel 1, diketahui bahwa jumlah responden pria lebih banyak dibanding responden wanita. Jumlah responden pria sebanyak 26 orang $(70,3 \%)$ dan wanita sebanyak 11 orang $(29,7 \%)$. Sebagian besar responden adalah berumur di atas 30 tahun yaitu sebanyak 28 orang $(75,7 \%)$, responden yang berumur antara 26 - 30 tahun sebanyak 4 orang $(10,8 \%), 3$ orang yang berumur antara $21-25$ tahun $(8,1 \%)$ dan hanya 2 orang yang berumur kurang dari 21 tahun $(5,4 \%)$. Selain itu berdasarkan Tabel 1 dapat diketahui bahwa 14 responden $(37,8 \%)$ berpendidikan S1, 13 responden $(35,1 \%)$ berpendidikan SMA, 8 responden $(21,6 \%)$ berpendidikan S2 dan hanya 2 responden $(5,4 \%)$ berpendidikan D3.

Berdasarkan omset usaha per tahun diketahui bahwa sebagian besar responden memiliki omset kurang dari Rp 300 juta per tahun (70,3\%), 9 responden memiliki omset $\mathrm{Rp}$ 300 juta - Rp 2,5 milyar per tahun (24,3\%), 1 responden memiliki omset $\mathrm{Rp} 2,5$ milyar - Rp 50 milyar per tahun $(2,7 \%)$, dan 1 responden memiliki omset lebih dari Rp 50 milyar per tahun $(2,7 \%)$. Lama usaha responden sebagai pelaku usaha di masing-masing UMKM bervariasi. Dari tabel 1 dapat diketahui jumlah responden yang lama usahanya di atas 3 tahun sebanyak 47 orang (92\%). Jumlah responden yang lama usahanya antara $2-3$ tahun sebanyak 3 orang $(6 \%)$ dan sisanya 1 orang responden $(2 \%)$ dengan lama usaha selama kurang dari 2 tahun.

Penelitian ini bertujuan untuk menganalisis faktor yang mempengaruhi tingkat kepercayaan penggunaan FinTech pada UMKM dengan menggunakan Technology Acceptance Model (TAM). Adapun variabel yang diteliti meliputi Kemampuan Menggunakan Komputer (CSE), Persepsi Kegunaan (POU), Persepsi Kemudahan Penggunaan (PEU), Sikap Pengguna (ATU), Minat Perilaku (BEI), dan Penggunaan Senyatanya (ACU). Statistik deskriptif dari masing-masing variabel penelitian dapat dilihat pada Tabel 2 berikut.

Tabel 2

Statistik Deskriptif

\begin{tabular}{lllll}
\hline \multicolumn{1}{c}{ Variabel Penelitian } & $\begin{array}{c}\text { Nilai } \\
\text { Minimum }\end{array}$ & $\begin{array}{c}\text { Nilai } \\
\text { Maksmum }\end{array}$ & Mean & $\begin{array}{c}\text { Std. } \\
\text { Deviasi }\end{array}$ \\
\hline $\begin{array}{l}\text { Kemampuan Menggunakan } \\
\text { Komputer (CSE) }\end{array}$ & 3 & 15 & 9,59 & 2,83 \\
$\begin{array}{l}\text { Persepsi Kegunaan (POU) } \\
\text { Persepsi Kemudahan }\end{array}$ & 4 & 20 & 14,84 & 3,72 \\
$\begin{array}{l}\text { Penggunaan (PEU) } \\
\text { Sikap Pengguna (ATU) }\end{array}$ & 3 & 20 & 13,84 & 3,82 \\
$\begin{array}{l}\text { Minat Perilaku (BEI) } \\
\text { Penggunaan Senyatanya }\end{array}$ & 3 & 15 & 10,84 & 2,88 \\
(ACU) & 3 & 15 & 10,86 & 2,71 \\
\hline
\end{tabular}

Sumber Data: Data Diolah

Berdasarkan tabel di atas diketahui bahwa variabel Kemampuan Menggunakan Komputer (CSE) memiliki nilai minimum sebesar 3, nilai maksimum sebesar 15 , dan nilai mean sebesar 9,59 dengan standar deviasi sebesar 2,83. Variabel Persepsi Kegunaan (POU) memiliki nilai minimum sebesar 4 , nilai maksimum sebesar 20, dan nilai mean sebesar 14,84 dengan standar deviasi sebesar 3,72. Variabel Persepsi Kemudahan Penggunaan 
(PEU) memiliki nilai minimum sebesar 4, nilai maksimum sebesar 20, dan nilai mean sebesar 14,84 dengan standar deviasi sebesar 3,82. Variabel Sikap Pengguna (ATU) memiliki nilai minimum sebesar 3, nilai maksimum sebesar 15, dan nilai mean sebesar 10,84 dengan standar deviasi sebesar 2,88. Variabel Minat Perilaku (BEI) memiliki nilai minimum sebesar 3, nilai maksimum sebesar 15 , dan nilai mean sebesar 10,86 dengan standar deviasi sebesar 2,71. Variabel Penggunaan Senyatanya (ACU) memiliki nilai minimum sebesar 3 , nilai maksimum sebesar 15 , dan nilai mean sebesar 8,24 dengan standar deviasi sebesar 2,55.

Signifikansi parameter yang diestimasi memberikan informasi yang sangat berguna mengenai hubungan antara variabel-variabel penelitian. Dasar yang digunakan dalam menguji hipotesis adalah nilai yang terdapat pada output result for inner weight. Tabel 3 menunjukkan output estimasi untuk pengujian model struktural.

Tabel 3

Result For Inner Weights

\begin{tabular}{lrrrrr}
\hline & Original & Sample & Standard & \multicolumn{1}{l}{ T } & \multicolumn{1}{l}{ P } \\
\hline ATU -> BEI & 0.689 & 0.691 & 0.174 & 3.958 & 0.00 \\
BEI -> ACU & 0.387 & 0.416 & 0.243 & 1.595 & 0.11 \\
CSE -> PEU & 0.777 & 0.778 & 0.061 & 12.66 & 0.00 \\
CSE -> POU & 0.177 & 0.167 & 0.099 & 1.795 & 0.07 \\
PEU -> ATU & 0.305 & 0.363 & 0.238 & 1.281 & 0.20 \\
PEU -> POU & 0.668 & 0.670 & 0.125 & 5.348 & 0.00 \\
POU -> ATU & 0.595 & 0.530 & 0.233 & 2.555 & 0.01 \\
\hline
\end{tabular}

Sumber data: Data diolah

\section{PEMBAHASAN}

Dalam PLS pengujian secara statistik setiap hubungan yang dihipotesiskan dilakukan dengan menggunakan simulasi. Dalam hal ini dilakukan metode bootstrap terhadap sampel. Pengujian dengan bootstrap juga dimaksudkan untuk meminimalkan masalah ketidaknormalan data penelitian. Hasil pengujian dengan bootstrapping dari analisis PLS adalah sebagai berikut:

a. Pengujian Hipotesis 1 (Kemampuan Menggunakan Komputer (CSE) Berpengaruh Positif terhadap Persepsi Kegunaan (POU) pada Perangkat Lunak FinTech)

Hasil pengujian hipotesis pertama menunjukkan bahwa hubungan variabel Kemampuan Menggunakan Komputer (CSE) dengan Persepsi Kegunaan (POU) menunjukkan nilai koefisien jalur sebesar 0,177 dengan nilai t statistics sebesar 1,795 dan $p$ value 0,073 . Oleh karena $p$ value
0,073 lebih besar dari 0,05 berarti bahwa Kemampuan Menggunakan Komputer (CSE) tidak memiliki hubungan yang positif yang signifikan terhadap Persepsi Kegunaan (POU). Hal ini berarti Hipotesis 1 ditolak.

b. Pengujian Hipotesis 2 (Kemampuan menggunakan komputer (CSE) Berpengaruh Positif terhadap Persepsi Kemudahan Penggunaan (PEU) pada Perangkat Lunak FinTech)

Hasil pengujian hipotesis kedua menunjukkan bahwa hubungan variabel Kemampuan Menggunakan Komputer (CSE) dengan Persepsi Kemudahan Penggunaan (PEU) menunjukkan nilai koefisien jalur sebesar 0,777 dengan nilai $\mathrm{t}$ statistics sebesar 12,662 dan $p$ value 0,000. Oleh karena $p$ value 0,000 lebih kecil dari 0,05 berarti bahwa Kemampuan Menggunakan Komputer (CSE) memiliki hubungan yang positif yang signifikan 
terhadap Persepsi Kemudahan Penggunaan (PEU). Hal ini berarti Hipotesis 2 diterima.

\begin{tabular}{lcrr} 
c. Pengujian & Hipotesis & 3 & (Persepsi \\
Kemudahan & \multicolumn{2}{c}{ Penggunaan } & (PEU) \\
Berpengaruh & Positif & terhadap & Persepsi \\
Kegunaan & (POU) & Perangkat & Lunak \\
FinTech) & & &
\end{tabular}

Hasil pengujian hipotesis ketiga menunjukkan bahwa hubungan variabel Persepsi Kemudahan Penggunaan (PEU) dengan Persepsi Kegunaan (POU) menunjukkan nilai koefisien jalur sebesar 0,668 dengan nilai t statistics sebesar 5,348 dan $p$ value 0,000 . Oleh karena $p$ value 0,000 lebih kecil dari 0,05 berarti bahwa Persepsi Kemudahan Penggunaan (PEU) memiliki hubungan yang positif yang signifikan terhadap Persepsi Kegunaan (POU). Hal ini berarti Hipotesis 3 diterima.

d. Pengujian Hipotesis 4 (Persepsi Kegunaan (POU) Berpengaruh Positif terhadap Sikap Pengguna (ATU) Perangkat Lunak FinTech)

Hasil pengujian hipotesis keempat menunjukkan bahwa hubungan variabel Persepsi Kegunaan (POU) dengan Sikap Pengguna (ATU) menunjukkan nilai koefisien jalur sebesar 0,595 dengan nilai $\mathrm{t}$ statistics sebesar 2,555 dan $p$ value 0,011. Oleh karena $p$ value 0,011 lebih kecil dari 0,05 berarti bahwa Persepsi Kegunaan (POU) memiliki hubungan yang positif yang signifikan terhadap Sikap Pengguna (ATU). Hal ini berarti Hipotesis 4 diterima.

e. Pengujian Hipotesis 5 (Persepsi Kemudahan Penggunaan (PEU) Berpengaruh Positif terhadap Sikap Pengguna (ATU) Perangkat Lunak FinTech)

Hasil pengujian hipotesis kelima menunjukkan bahwa hubungan variabel Persepsi Kemudahan Penggunaan (PEU) dengan Sikap Pengguna (ATU) menunjukkan nilai koefisien jalur sebesar 0,305 dengan nilai t statistics sebesar 1,281 dan $p$ value 0,201 . Oleh karena $p$ value 0,201 lebih besar dari 0,05 berarti bahwa Persepsi Kemudahan Penggunaan (PEU) tidak memiliki hubungan yang positif yang signifikan terhadap Sikap Pengguna (ATU). Hal ini berarti Hipotesis 5 ditolak.

f. Pengujian Hipotesis 6 (Sikap Pengguna (ATU) Perangkat Lunak FinTech Berpengaruh Positif terhadap Minat Perilaku (BEI))

Hasil pengujian hipotesis keenam menunjukkan bahwa hubungan variabel Persepsi Sikap Pengguna (ATU) dengan Minat Perilaku (BEI) menunjukkan nilai koefisien jalur sebesar 0,689 dengan nilai $\mathrm{t}$ statistics sebesar 3,958 dan $p$ value 0,000. Oleh karena $p$ value 0,000 lebih kecil dari 0,05 berarti bahwa Sikap Pengguna (ATU) memiliki hubungan yang positif yang signifikan terhadap Minat Perilaku (BEI). Hal ini berarti Hipotesis 6 diterima.

g. Pengujian Hipotesis 7 (Minat perilaku (BEI) Berpengaruh Positif terhadap Penggunaan Senyatanya (ACU) Perangkat Lunak FinTech)

Hasil pengujian hipotesis ketujuh menunjukkan bahwa hubungan variabel Minat Perilaku (BEI) dengan Penggunaan Senyatanya (ACU) menunjukkan nilai koefisien jalur sebesar 0,387 dengan nilai $\mathrm{t}$ statistics sebesar 1,595 dan $p$ value 0,111 . Oleh karena $p$ value 0,111 lebih besar dari 0,05 berarti bahwa Minat Perilaku (BEI) tidak memiliki hubungan yang positif yang signifikan terhadap Penggunaan Senyatanya (ACU). Hal ini berarti Hipotesis 7 ditolak.

\section{KESIMPULAN DAN SARAN}

\section{Kesimpulan}

Penelitian yang telah dilakukan telah memberikan hasil sebagai berikut: 
a. Pengujian Hipotesis 1 tidak menunjukkan bahwa Kemampuan Menggunakan Komputer (CSE) Berpengaruh Positif terhadap Persepsi Kegunaan (POU) pada Perangkat Lunak FinTech. Hal ini menunjukkan bahwa pengguna atau dalam hal ini yaitu pegiat UMKM mempunyai persepsi bahwa fintech berguna meskipun mereka tidak mempunyai kemampuan memadai dalam menggunakan komputer.

b. Pengujian Hipotesis 2 menunjukkan bahwa Kemampuan menggunakan komputer (CSE) Berpengaruh Positif terhadap Persepsi Kemudahan Penggunaan (PEU) pada Perangkat Lunak FinTech. Hal ini berarti bahwa dengan adanya kemampuan dalam menggunakan komputer, maka pengguna atau pegiat UMKM akan merasa mudah dalam memanfaatkan Fintech.

c. Pengujian Hipotesis 3 menunjukkan bahwa Persepsi Kemudahan Penggunaan (PEU) Berpengaruh Positif terhadap Persepsi Kegunaan (POU) Perangkat Lunak FinTech. $\mathrm{Hal}$ ini menunjukkan bahwa pengguna atau pegiat UMKM memandang bahwa Fintech yang mudah digunakan akan memberikan kegunaan atau manfaat kepada mereka.

d. Pengujian Hipotesis 4 menunjukkan bahwa Persepsi Kegunaan (POU) Berpengaruh Positif terhadap Sikap Pengguna (ATU) Perangkat Lunak FinTech. Hal ini menunjukkan bahwa pengguna atau pegiat UMKM yang mempunyai persepsi bahwa Fintech memiliki kegunaan akan mempengaruhi sikap mereka dalam penggunaan Fintech.

e. Pengujian Hipotesis 5 tidak menunjukkan bahwa Persepsi Kemudahan Penggunaan (PEU) Berpengaruh Positif terhadap Sikap Pengguna (ATU) Perangkat Lunak FinTech. Hal ini menunjukkan bahwa pengguna atau pegiat UMKM yang mempunyai persepsi bahwa Fintech mudah digunakan tidak akan mempengaruhi sikap mereka dalam penggunaan Fintech, pengguna menyadari dengan adanya kemajuan teknologi mau tidak mau maka mereka harus menyesuaikan sikap mereka.

f. Pengujian Hipotesis 6 menunjukkan bahwa Sikap Pengguna (ATU) Perangkat Lunak FinTech Berpengaruh Positif terhadap Minat Perilaku (BEI). Hal ini menunjukkan bahwa pengguna atau pegiat UMKM mempunyai sikap bahwa dengan adanya Fintech maka mereka akan merubah kebiasaan atau perilaku mereka sesuai dengan kemajuan teknologi Fintech agar tetap relevan dengan perkembangan jaman.

g. Pengujian Hipotesis 7 tidak menunjukkan bahwa Minat perilaku (BEI) Berpengaruh Positif terhadap Penggunaan Senyatanya (ACU) Perangkat Lunak FinTech. Hal ini menunjukkan bahwa pengguna atau pegiat UMKM meskipun mempunyai minat untuk menggunakan Fintech namun masih enggan untuk memanfaatkan Fintech, beberapa dikarenakan oleh teknologi Fintech yang masih tergolong baru, keamanan data pengguna Fintech, dan lainnya.

\section{Saran}

Penelitian ini menunjukkan bahwa Fintech yang mulai dilihat sebagai salah satu alternatif permodalan selain perbankan dalam industri UMKM secara umum telah mempunyai citra positif. Namun tetap saja para pegiat UMKM terutama di daerah Yogyakarta masih enggan untuk memanfaatkan secara optimal, hal tersebut bisa disebabkan kurangnya sosialisasi terhadap FIntech di kalangan UMKM Yogyakarta, atau karena masih adanya beberapa ancaman dalam penggunaan Fintech, misalnya seperti keamanan data pengguna, hingga ke tindakan pencucian uang melalui Fintech. Penelitian ini mendukung adanya regulasi yang telah ditetapkan OJK untuk menjamin keamanan dan kenyamanan para pegiat UMKM dalam memanfaatkan Fintech. 


\section{DAFTAR REFERENSI}

Abessi, Masoud \& Haghighy, Tahereh K., 2009, "Internet Banking Technology Acceptance Model: a Focus On Hofstede Cultural Dimensions", available at: http://ssrn.com/abstract $=1898715$

Kim, Yonghee J., 2015, “An Empirical Study on the Adoption of "Fintech" Service: Focused on Mobile Payment Services". Advanced Science and Technology Letters Vol.114 (Business 2015), pp.136-140., http://dx.doi.org/10.14257/astl.2015.114. $\underline{26}$

Arner, Douglas W., 2016. "Fintech: Evolution and Regulation", Asian Institute of International Financial Law University of Hong Kong http://law.unimelb.edu.au/_data/assets/ pdf_file/0011/1978256/D-ArnerFinTech-Evolution-Melbourne-June2016.pdf

Chrismastianto, Imanuel A.W., 2017, "Analisis SWOT Implementasi Teknologi Finansial Terhadap Kualitas Layanan Perbankan Di Indonesia", Jurnal Ekonomi dan Bisnis, Volume 20 No. 1, April 2017, ISSN 1979 - 6471.

Ghozali, Imam, 2014. "Structural Equation Modelling, Metode Alternatif dengan Partial Least Square (PLS)." Edisi 4. Semarang: Badan Penerbit Universitas Diponegoro.

Rahayu, Imam S., 2015, "Minat Nasabah Menggunakan Mobile Banking Dengan Menggunakan Kerangka Technology Acceptance Model (TAM) (Studi Kasus PT Bank Syariah Mandiri Cabang Yogyakarta), JURNAL EKONOMI SYARIAH INDONESIA, Volume V, No.2 Desember 2015.

Hermanto, Suwardi B. \& Patmawati, 2017, Determinan Penggunaan Aktual Perangkat Lunak Akuntansi Pendekatan Technology Acceptance Model, Jurnal Akuntansi dan Keuangan, Vol. 19, No. 2, November 2017, 67-81, DOI: 10.9744/jak.19.2.67-81. ISSN 14110288 print / ISSN 2338-8137 online.
Jogiyanto \& Willy A., 2009, "Konsep \& Aplikasi PLS untuk Penelitian Empiris" BPFE, Yogyakarta.

Napitupulu, Darmawan., 2017, Kajian Penerimaan E-Learning Dengan Pendekatan TAM, Prosiding Seminar Nasional Multidisiplin Ilmu Universitas Budi Luhur, Jakarta 22 April 2017, ISSN : 2087 - 0930 ICT - 41

Fatmawati, Endang., 2015, “Technology Acceptance Model (TAM) Untuk Menganalisis Penerimaan Terhadap Sistem Informasi Perpustakaan", Jurnal Iqra' Volume 09 No.01 Mei, 2015.

Farokhah, Lia \& Afiyah, Siti N., 2016, "Pengukuran Penerimaan Sistem Kartu Rencana Studi (SIMAKA) di STMIK Asia Malang Menggunakan Technology Acceptance Model (TAM) Modifikasi Hwang dan Yi", Jurnal Ilmiah Teknologi dan Informasia ASIA (JITIKA), Vol.10, No.1, Februari 2016. ISSN: 0852-730X. 